\title{
Clinical characteristics of the primary hepatic malignant fibrous histiocytoma in China: case report and review of the literature
}

\author{
Dianbo Yao and Chaoliu Dai
}

\begin{abstract}
Background: A malignant fibrous histiocytoma is a soft tissue tumor that most commonly occurs in the extremities, but rarely involves the liver. The clinical characteristics and therapeutic experiences of primary hepatic malignant fibrous histiocytoma are still limited.

Methods: Two cases of primary hepatic malignant fibrous histiocytoma were analyzed retrospectively, and all the literature concerning primary hepatic malignant fibrous histiocytoma was analyzed.

Results: In China, a total of 76 cases had been reported, among which 50 were men, with a male to female ratio of 1.9:1. Mean age of the patients was 51.0 years old, and more than 85 percent were older than 40 years. 82.9 percent (63/76) of hepatic MFH were solitary lesions, with tumor size ranging from 2.5 to $23.5 \mathrm{~cm}$ (average 10.3 $\mathrm{cm}$ ). Major clinical presentation (78.4\%) was abdominal pain or discomfort, accompanied with some other nonspecific symptoms such as malaise, anorexia, weight loss, jaundice and fever, and small cases (14.9\%) were asymptomatic. Computed tomography and ultrasound usually revealed the location of lesions. The rate of preoperative misdiagnosis was extremely high, and 14.9 percent of patients were even misdiagnosed as a benign liver cyst, liver abscess or hematoma. Integrated resection was performed among the most cases (49/68), among which only a few ones (12 cases) were introduced to have no recurrence or metastasis or be still alive with no detail information provided, while among the cases with palliative operation or only a biopsy, the cases that were followed-up all died.
\end{abstract}

Conclusions: Hepatic malignant fibrous histiocytoma is a rare malignant mesenchymal tumor. The variable features of clinical presentations and images make the diagnosis difficult. Though the prognosis of primary hepatic malignant fibrous histiocytoma was rather poor, integrated resection might provide a few cases a good opportunity for surviving, suggesting that surgery might be an effective treatment.

Keywords: Malignant fibrous histiocytoma, Liver neoplasms, Diagnosis, Therapy

\section{Background}

Since its initial description in 1964 by O'Brien and Stout [1], malignant fibrous histiocytoma (MFH) has been regarded as one of the most common soft tissue sarcomas of late adult life[2]. MFH primarily occurs in the extremities and less commonly involves the retroperitoneal spaces, abdominal cavity, or other sites [3]. The primary hepatic MFH is extremely rare, and there is still an incomplete understanding of the clinicopathology of

\footnotetext{
* Correspondence: daicl@sj-hospital.org

Department of Hepatobiliary and Splenic Surgery, Shengjing Hospital of China Medical University, Shenyang, Liaoning Province, China
}

primary hepatic MFH. In this study, two cases of primary hepatic MFH treated in our hospital are reported, and the literature of Chinese cases before June 2011 was reviewed and analyzed, to provide a better understanding of the clinicopathologic characteristics of this rare entity with an emphasis on its clinical characteristics and therapeutic experiences.

\section{Materials and methods}

Clinical records of two patients with primary hepatic MFH treated from 2006 to June 2011 at the Shengjing Hospital of China Medical University were 
retrospectively reviewed. Surgeries were carried out in both patients, and the diagnosis was pathologically confirmed. Both of the patients were males, and their ages were 56 and 62 years old respectively. Routine preoperative examinations (physical examination, blood tests, ultrasonography, CT and/or MRI) and relevant tumor marker tests (A-fetoprotein, carcinoembryonic antigen and/or CA 19.9) were performed. One patient was followed up, while the other was lost.

China Academic Journal Full-text Database (CNKI), Chinese Scientific Journals Database (VIP) and Wan fang Database were used for searching Chinese reports about hepatic MFH before June 2011. Articles from the same institution were carefully studied to avoid the repetitive adoption of the saved material, and 50 articles including 91 cases were found.

A database including age, gender, symptoms, location, size of the tumor, metastasis or invasion of adjacent tissues, treatment and prognosis was created with all patients' characteristics. Every case that had at least six of these eight elements was characterized as well-documented. All of the non well-documented cases were excluded. 42 articles including 74 well-documented cases of primary hepatic MFH were left. Among the 74 cases, 3 cases were excluded because they were diagnosed as myxoid MFH which was no longer a subtype of MFH according to the 2002 WHO classification [4].

In addition, in the English literature, a total of 45 reported cases of primary hepatic MFH were found [5-31] (Table 1). Among the 45 cases, 8 cases were from China, and the related information of 5 cases in these 8 cases was also introduced in the Chinese literature. So finally, including 2 cases in our hospital, 76 cases of primary hepatic MFH in China were included in this review and analysis.

\section{Results}

\section{Characteristic Features of Our Study Patients Case 1}

A 56-year-old man presented with discomfort in the right upper abdominal quadrant, nausea, without weight loss. Physical examination revealed a soft, non-tender abdomen. Ultrasonography (Figure 1A, B) revealed a hypoechoic mass with unmarked arrangement in the right posterior lobe. The echogenicity was inhomogeneous, and color Doppler study showed no pulsative flow signals, suggesting low vascularity in the mass. Non-enhancement CT (Figure 1C) showed a heterogeneous mass with areas of cystic changes in the right lobe. The size of the lesion was $6.8 \times 6.6 \mathrm{~cm}$, and the lesion was ill demarcated with the surrounding hepatic parenchyma. On contrast enhancement CT (Figure 1DF), solid components showed slight enhancement, while the cystic components were never enhanced. Laboratory data showed that the liver function tests were all within normal ranges. $\mathrm{HBsAg}$ and $\mathrm{HBcAb}$ were positive. Levels of alpha-fetoprotein (AFP), carcinoembryonic antigen (CEA) and carbohydrate antigen 19-9 (CA 19-9) in serum were all within normal limits. Ultrasound-guided needle biopsy was performed, but the histopathological findings were only necrotic tissues. Pre-operative diagnosis was hepatic neoplasm, and local resection of the right lobe was performed. The surgical specimen measured $8 \mathrm{~cm}$, and the mass was mostly solid, brown and partially white in colour, with focal necrotic and hemorrhagic foci. The pathological diagnosis was primary hepatic pleomorphic storiform MFH. Immunohistochemically, the tumor cells showed positive for vimentin, while stains for CK, EMA, Calponin, CD34, AFP, hepatocyte and S-100 were all negative. The patient has been followed up for 6 months to date, and is still alive, without a recurrence.

\section{Case 2}

A 63-year-old man presented with intermittent twinge pain in the right upper abdominal quadrant for 10 days, without radiating pain, fever or weight loss. Physical examination on admission revealed that abdomen is flat and soft, and tenderness was in right upper abdomen, without rebound tenderness. Liver and spleen was untouched. MRI examination (Figure 2A-F) revealed a mass that was ill delineated from surrounding liver parenchyma, and the main signal intensity of the mass was hypo-intense compared with the liver, similar to that of skeletal muscle on T1-weighted imaging. The main signal intensity of the mass on T2-weighted images was higher than that in the liver, renal cortex or spleen. At subsequent CT (Figure 2G-L), a heterogeneous multinodular mass was confirmed, occupying the segment 6 . The mass was slightly enhanced during the arterial phase of contrast enhancement, and the enhancement was decreased during the portal and delayed phase. Emission Computed Tomography (ECT) suggested that there was no formation of bone metastasis. Laboratory data showed a white blood cell count of $11.9 \times 109 / \mathrm{L}$, hemoglobin level of $131 \mathrm{~g} / \mathrm{L}$ and a platelets count of $179 \times 109 / \mathrm{L}$. The liver function tests were all within normal ranges. Viral Hepatitis Testing revealed that HBsAg and HBcAb were positive. Alpha-Fetoprotein (AFP) was $1111.93 \mathrm{~g} / \mathrm{l}(\mathrm{RR},<25 \mathrm{~g} / \mathrm{l})$, and carbohydrate antigenic determinant (CA 19-9) was $12.46 \mathrm{u} / \mathrm{ml}$ (RR, < $37 \mathrm{u} / \mathrm{ml}$ ). Pre-operative diagnosis was hepatic neoplasm, and the patient then underwent local resection of the right lobe. The cut surface of the resected tumor showed a multi-nodule appearance with necrosis, and gray yellow in colour. The pathological diagnosis was primary pleomorphic storiform MFH. Immunohistochemically, the tumor cells showed positive for vimentin and CD68, while stains for CK, CK8/18, CD35, CD21, 
Table 1 Clinical Features of 45 Cases of Primary Hepatic Malignant Fibrous Histiocytoma in the English literature

\begin{tabular}{|c|c|c|c|c|c|c|c|c|c|}
\hline \multicolumn{2}{|c|}{$\begin{array}{l}\text { References/ } \\
\text { Published } \\
\text { date }\end{array}$} & \multirow{2}{*}{$\begin{array}{l}\text { Authors } \\
\text { Alberti-Flor et al }\end{array}$} & \multirow{2}{*}{$\begin{array}{l}\text { No. } \\
\text { Cases }\end{array}$} & \multirow{2}{*}{$\begin{array}{l}\text { Age/ } \\
\text { Sex } \\
59 / M\end{array}$} & \multirow{2}{*}{$\begin{array}{l}\text { Presentation } \\
\text { Abdominal pain, } \\
\text { anorexia, low fever, } \\
\text { weight loss }\end{array}$} & \multirow{2}{*}{$\begin{array}{l}\text { Location } \\
\\
\begin{array}{l}\text { Right and left } \\
\text { lobe }\end{array}\end{array}$} & \multirow{2}{*}{$\begin{array}{l}\begin{array}{l}\text { Size } \\
\text { (Largest } \\
\text { Dimension, } \\
\text { (m) }\end{array} \\
18\end{array}$} & \multirow{2}{*}{$\begin{array}{l}\text { Therapy } \\
\text { Surgery }\end{array}$} & \multirow{2}{*}{$\begin{array}{l}\begin{array}{l}\text { Follow-up/ } \\
\text { Outcome }\end{array} \\
2 \text { w/died of } \\
\text { tumor }\end{array}$} \\
\hline 5 & 1985 & & & & & & & & \\
\hline 6 & 1985 & Conran et al & 1 & $61 / M$ & $\begin{array}{l}\text { Abdominal pain, } \\
\text { anorexia, jaundice, } \\
\text { weight loss }\end{array}$ & Right and left & 7 & Puncture biopsy & $\begin{array}{l}18 \mathrm{~d} / \text { died of } \\
\text { tumor }\end{array}$ \\
\hline 7 & 1986 & Fukayama et al & 1 & $38 / F$ & Hepatic mass & Left lobe & 7 & Surgery & $\begin{array}{l}4 \text { y/alive without } \\
\text { recurrence }\end{array}$ \\
\hline 8 & 1987 & Arends et al & 1 & $78 / F$ & $\begin{array}{l}\text { Abdominal discomfort, } \\
\text { anorexia,shortness of } \\
\text { breath; }\end{array}$ & $\begin{array}{l}\text { Right and left } \\
\text { lobe }\end{array}$ & $>10$ & Palliative & $\begin{array}{l}6 \mathrm{~d} / \text { died of } \\
\text { tumor }\end{array}$ \\
\hline \multirow[t]{2}{*}{9} & \multirow[t]{2}{*}{1988} & \multirow[t]{2}{*}{ Bruneton et al } & \multirow[t]{2}{*}{2} & $52 / F$ & Abdominal pain & Right lobe & 10 & Surgery & $\begin{array}{l}2 \text { y/alive without } \\
\text { recurrence }\end{array}$ \\
\hline & & & & $34 / M$ & Abdominal pain & Right lobe & 13 & Palliative operation & $\begin{array}{l}6 \text { mo/died of } \\
\text { tumor }\end{array}$ \\
\hline 10 & 1988 & Honda et al & 1 & $71 / F$ & $\begin{array}{l}\text { Weight loss, fatigue, } \\
\text { fever }\end{array}$ & Right lobe & $>10$ & $\begin{array}{l}\text { Puncture biopsy, } \\
\text { chemoembolization }\end{array}$ & $\begin{array}{l}4 \text { mo/died of } \\
\text { tumor }\end{array}$ \\
\hline 11 & 1988 & Katsuda et al & 1 & $61 / M$ & Abdominal discomfort & Right lobe & 8.5 & $\begin{array}{l}\text { Surgery and } \\
\text { chemotherapy }\end{array}$ & $\begin{array}{l}6 \text { mo/died of } \\
\text { tumor }\end{array}$ \\
\hline 12 & 1991 & Hamasaki et al & 1 & $35 / M$ & $\begin{array}{l}\text { Abdominal fullness, } \\
\text { palpable mass }\end{array}$ & Left lobe & 9.1 & $\begin{array}{l}\text { Surgery, Intraarterial } \\
\text { therapy, later liver } \\
\text { transplant }\end{array}$ & $\begin{array}{l}34 \mathrm{mo} / \text { died of } \\
\text { lung metastasis }\end{array}$ \\
\hline 13 & 1992 & Akifuji et al & 1 & $79 / M$ & Anorexia, fatigue & Left lobe & 8 & $\begin{array}{l}\text { Chemoembolization, } \\
\text { Surgery }\end{array}$ & 5 mo/recurrence \\
\hline 14 & 1992 & Zornig et al & 1 & $36 / F$ & Abdominal pain & N/A & 7 & $\begin{array}{l}\text { Surgery, postoperate } \\
\text { chemotherapy }\end{array}$ & $\begin{array}{l}63 \text { mo/alive } \\
\text { without tumor }\end{array}$ \\
\hline 15 & 1992 & McGrady et al & 1 & $53 / F$ & Left-sided chest pain & Left lobe & $\begin{array}{l}14 \\
\text { (operation) }\end{array}$ & $\begin{array}{l}\text { Surgery, } 5 \text { years later } \\
\text { recured, surgery } \\
\text { again }\end{array}$ & $\begin{array}{l}9 \text { y/alive without } \\
\text { tumor after } \\
\text { second surgery }\end{array}$ \\
\hline 16 & 1993 & Reed et al & 1 & $52 / \mathrm{M}$ & Spike fever & Right lobe & $>10$ & $\begin{array}{l}\text { Surgery, postoperate } \\
\text { chemotherapy }\end{array}$ & $\begin{array}{l}2 \mathrm{mo} / \text { died of } \\
\text { metastasis }\end{array}$ \\
\hline 17 & 1994 & Pinson et al & 1 & $41 / \mathrm{M}$ & $\begin{array}{l}\text { Abdominal pain, } \\
\text { weight loss }\end{array}$ & Right and left & 11.5 & Surgery & $\begin{array}{l}10 \text { and a half } \\
\text { mo/died of } \\
\text { recurrence and } \\
\text { metastasis }\end{array}$ \\
\hline 18 & 1998 & Fujita et al & 1 & $70 / \mathrm{M}$ & $\begin{array}{l}\text { Malaise, anorexia, } \\
\text { fever, weight loss }\end{array}$ & Right and left & 12 & $\begin{array}{l}\text { Puncture biopsy, } \\
\text { Surgery }\end{array}$ & $\begin{array}{l}3 \text { mo/died of } \\
\text { tumor }\end{array}$ \\
\hline 19 & 1998 & $\begin{array}{l}\text { Wunderbaldinger } \\
\text { et al }\end{array}$ & 1 & $56 / F$ & $\begin{array}{l}\text { Palpable mass, lower } \\
\text { extremity swelling }\end{array}$ & Right lobe & $>10$ & Surgery & N/A \\
\hline \multirow[t]{3}{*}{$20^{+}$} & \multirow[t]{3}{*}{1998} & \multirow[t]{3}{*}{ Ferrozzi et al } & \multirow[t]{3}{*}{3} & $62 / F^{\dagger}$ & $\begin{array}{l}\text { Abdominal pain, } \\
\text { malaise, low-grade } \\
\text { fever, and weight loss }\end{array}$ & Right lobe & $>12$ & Surgery & $\begin{array}{l}3 \text { y/alive without } \\
\text { recurrence }\end{array}$ \\
\hline & & & & $67 / F$ & $\begin{array}{l}\text { Abdominal pain, } \\
\text { weight loss, malaise } \\
\text { and palpable mass. }\end{array}$ & Right and left & $>12$ & $\begin{array}{l}\text { Biopsy, palliative } \\
\text { chemotherapy. }\end{array}$ & N/A \\
\hline & & & & $69 / M$ & $\begin{array}{l}\text { Abdominal pain, } \\
\text { weight loss, fatigue } \\
\text { and anorexia. }\end{array}$ & Right and left & $>12$ & $\begin{array}{l}\text { Puncture biopsy, } \\
\text { palliative } \\
\text { chemotherapy }\end{array}$ & N/A \\
\hline $21^{\dagger}$ & 1999 & Yu et al & 5 & $\begin{array}{l}40-69 \\
(53) / \\
4 \mathrm{M} \\
1 \mathrm{~F}\end{array}$ & $\begin{array}{l}\text { Abdominal } \\
\text { discomfort*4, right } \\
\text { shoulder and chest } \\
\text { pain*1 }\end{array}$ & $\begin{array}{l}\text { Right lobe *3, } \\
\text { left lobe *2 }\end{array}$ & $\begin{array}{l}\text { 7-19 (mean } \\
\text { 13) }\end{array}$ & Surgery*5 & $N / A^{*} 5$ \\
\hline 22 & 1999 & Maekawa et al & 1 & $68 / M$ & Malaise & Right lobe & 6 & Surgery & N/A \\
\hline 23 & 2005 & $\begin{array}{l}\text { Anagnostopoulos } \\
\text { et al }\end{array}$ & 1 & $87 / F$ & $\begin{array}{l}\text { Abdominal pain, } \\
\text { weight loss, low fever }\end{array}$ & Right lobe & $12(\mathrm{CT})$ & Puncture biopsy & $\begin{array}{l}6 \mathrm{mo} / \mathrm{died} \text { of } \\
\text { tumor }\end{array}$ \\
\hline 24 & 2006 & Ding et al & 1 & $50 / M$ & $\begin{array}{l}\text { Abdominal pain, } \\
\text { fatigue, weight loss }\end{array}$ & Right and left & $14.2(\mathrm{CT})$ & $\begin{array}{l}\text { Biopsy after } \\
\text { laparotomy }\end{array}$ & $\begin{array}{l}2 \text { mo/died of } \\
\text { tumor }\end{array}$ \\
\hline
\end{tabular}


Table 1 Clinical Features of 45 Cases of Primary Hepatic Malignant Fibrous Histiocytoma in the English literature (Continued)

\begin{tabular}{|c|c|c|c|c|c|c|c|c|c|}
\hline $25^{\ddagger}$ & 2007 & Ye et al & 1 & $50 / \mathrm{M}$ & $\begin{array}{l}\text { Abdominal pain, } \\
\text { weight loss }\end{array}$ & Left lobe & 16 & Surgery & $\begin{array}{l}4 \mathrm{mo} / \text { died of } \\
\text { recurrence and } \\
\text { metastasis }\end{array}$ \\
\hline 26 & 2007 & Chen et al & 1 & $70 / \mathrm{M}$ & $\begin{array}{l}\text { Abdominal pain, } \\
\text { weight loss }\end{array}$ & Right lobe & $12.4(\mathrm{CT})$ & Palliative operation & $\begin{array}{l}1 \text { mo/died of } \\
\text { tumor }\end{array}$ \\
\hline \multirow[t]{7}{*}{$27^{\dagger}$} & 2008 & Li et al & 7 & $77 / F$ & $\begin{array}{l}\text { Spiking fever, weight } \\
\text { loss }\end{array}$ & Right lobe & 10 & Lobectomy & $1 \mathrm{y} /$ died of tumor \\
\hline & & & & $54 / \mathrm{M}$ & $\begin{array}{l}\text { Abdominal pain, } \\
\text { weight loss }\end{array}$ & Left lobe & 5.5 & Lobectomy & $4 \mathrm{y} /$ died of tumor \\
\hline & & & & $34 / F$ & Abdominal pain & Right lobe & 14 & $\begin{array}{l}\text { Liver and lung } \\
\text { Lobectomy }\end{array}$ & $\begin{array}{l}4 \text { mo/died of } \\
\text { tumor }\end{array}$ \\
\hline & & & & $80 / F$ & $\begin{array}{l}\text { Abdominal discomfort, } \\
\text { weight loss }\end{array}$ & Right lobe & 20 & Palliative & $1 \mathrm{y} /$ died of tumor \\
\hline & & & & $68 / F$ & Abdominal pain & Right and left & 2 & $\mathrm{~N} / \mathrm{A}$ & N/A \\
\hline & & & & $46 / F$ & Abdominal pain & Right lobe & 12 & Gleevecineffective & $\begin{array}{l}3 \text { mo/alive, tumor } \\
\text { larger but no } \\
\text { metastasis }\end{array}$ \\
\hline & & & & $\begin{array}{l}70 / \\
\mathrm{M}^{+}\end{array}$ & Incidental finding & Right lobe & 11 & Lobectomy & $4 \mathrm{y} /$ no recurrence \\
\hline \multirow[t]{2}{*}{28} & 2009 & Sugitani et al & 2 & $45 / F$ & Abdominal pain & Left lobe & 11 & $\begin{array}{l}\text { Surgery, } 2 \text { years and } \\
5 \text { months later } \\
\text { recured, surgery } \\
\text { again }\end{array}$ & $\begin{array}{l}34 \text { mo/died of } \\
\text { tumor metastasis }\end{array}$ \\
\hline & & & & $70 / F$ & Jaundice & Right lobe & 12 & $\begin{array}{l}\text { Preoperate } \\
\text { chemotherapy, } \\
\text { Surgery }\end{array}$ & $\begin{array}{l}8 \mathrm{mo} / \text { died of } \\
\text { tumor metastasis }\end{array}$ \\
\hline 29 & 2009 & Kim et al & 1 & $60 / M$ & $\begin{array}{l}\text { Abdominal pain, } \\
\text { weight loss }\end{array}$ & Right lobe & 14 & Surgery & $\begin{array}{l}41 \text { mo/alive } \\
\text { without } \\
\text { recurrence }\end{array}$ \\
\hline 30 & 2010 & Caldeira et al & 1 & $63 / M$ & $\begin{array}{l}\text { Abdominal discomfort, } \\
\text { lower extremities } \\
\text { edema and weight } \\
\text { loss. }\end{array}$ & Right lobe & $\mathrm{N} / \mathrm{A}$ & Puncture biopsy & $\begin{array}{l}45 \mathrm{~d} / \text { died of } \\
\text { tumor }\end{array}$ \\
\hline 31 & 2011 & Cong et al & 5 & $\begin{array}{l}50-71 \\
(59) / \\
2 \mathrm{M} \\
3 \mathrm{~F}\end{array}$ & $\begin{array}{l}\text { Abdominal pain or } \\
\text { discomfort*4, weight } \\
\text { loss }^{* 1}\end{array}$ & $\begin{array}{l}\text { Right lobe }{ }^{*} 2 \text {, } \\
\text { left lobe }{ }^{*} 1, \text { right } \\
\text { and left }{ }^{*} 1, N / A^{*} 1\end{array}$ & $2.5-16$ & Surgery* 5 & $\mathrm{~N} / \mathrm{A}^{*} 5$ \\
\hline
\end{tabular}

† indicates containing cases that were diagnosed as myxoid MFH; $\neq$ giant cell-type MFH

CD1a, S-100, HMB45, MelanA, SMA, LCA were all negative. The patient was lost to follow-up.

\section{Analysis of reports in China}

Cases in China (including 2 patients in our series and 8 cases reported in the English literature)

Combined with the 2 patients in our series, 76 patients in China have been reported (Table 2). Among the 76 patients, 50 were men, with a male to female ratio of 1.9:1. The mean age of the 71 patients which have a clear age or mean age record was 51.0 years old (range, $10-77$ years), and 88.1 percent $(52 / 59)$ of the patients were older than 40 years.

Most of hepatic MFH were large neoplasms, and only 13.2 percent $(10 / 76)$ were smaller than $5 \mathrm{~cm}$. The exact sizes of hepatic MFH were mentioned in 59 cases, including 19 cases with diameter descriptions in radiolo- gical investigations. The mean diameter was $10.3 \mathrm{~cm}$ (range, 2.5-23.5 cm).

Among the 76 cases, 82.9 percent (63 cases) of the tumors were described as solitary lesions, while only 17.1 percent of the tumors were composed of multiple lesions. The information of tumor localization was provided in 66 cases, including 10 cases with multiple tumor nodules. Among the 10 cases, the tumor nodules of 4 cases were found in both right and left lobes and the tumor nodules of the remaining 6 cases were confined to one lobe of the liver, 3 in the left and 3 in the right lobe. Among the 56 cases with a solitary lesion, tumors were often found in the right lobe (33 cases), and less frequently in the left lobe (21 cases), and the lesions of the remaining 2 cases (3.6\%) were in the middle part of the liver.

For clinical manifestation of hepatic MFH, 74 cases provided details. The symptoms were usually non- 


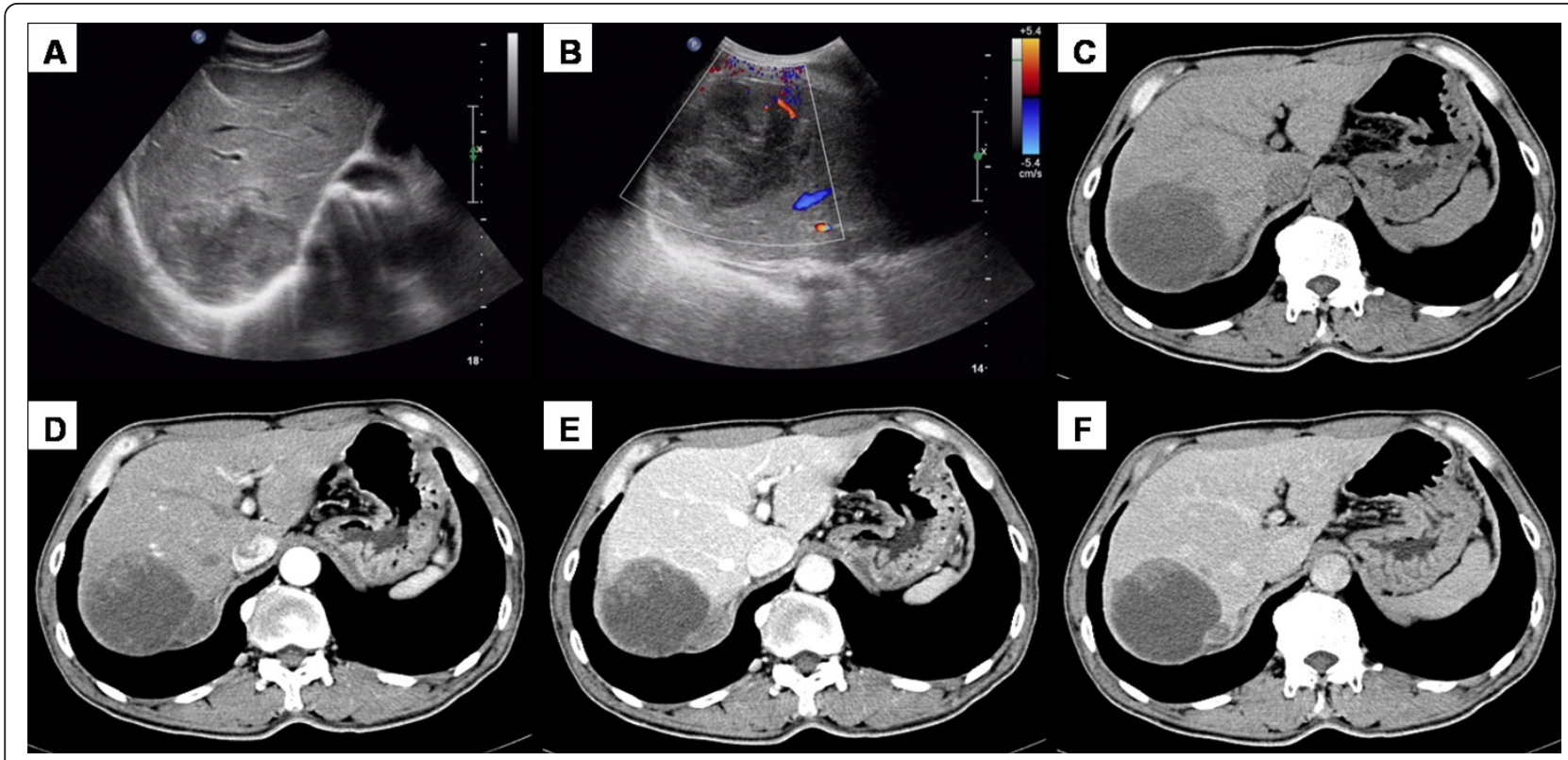

Figure 1 A 56-year-old man with abdominal discomfort. (A, B) Abdominal sonography revealed a hypoechoic mass with low vascularity. (C) Non-enhancement $C T$ showed a heterogeneous hypodense mass with areas of cystic changes in the right lobe. (D- F) After the contrast injection, the mass was slightly enhanced, especially on the edge.

specific. 58 patients (78.4\%) complained of abdominal pain or discomfort of different degrees, accompanied with loss of body weight in 12 cases, obstructive jaundice in 1 case, nausea and anorexia in 8 cases, and fever in 15 cases, including 2 cases with the temperature more than 39 degree. Nearly 14.9 percent (11 cases) of the patients were asymptomatic, with the tumors found during routine physical examinations or unrelated conditions. In addition, 2 patients were admitted to hospital for obstructive jaundice and 2 patients were for fever. The last one patient was admitted for loss of body weight and the lesion was found by the radiological investigation on admission.

A variety of radiological investigations were performed for the evaluation, including ultrasonography (US, 46 cases) and computed tomography (CT, 63 cases) in the vast majority of the patients, and magnetic resonance imaging (MRI) in only 16 patients. The tumors were described on cross-sectional imaging as solid, cystic or heterogeneous (solid and cystic) masses. Among the US investigations of 46 cases, 34 cases provided details. The tumors appeared hypoechoic in 10 cases, hyperechoic in 10 cases, anechoic in 2 cases, and showed a mixed pattern that may include extensive necrotic areas in 8 cases. In addition, the tumors were described as cystlike lesions in 2 cases. Among the remaining 2 cases, the lesions of one case were not detected and the other case had a lesion in each lobe of the liver, a cyst-like lesion in the left lobe and a hypoechoic lesion in the right. We have detail CT descriptions of 49 cases. The lesions that were not detected in the US investigation were not detected either in the CT investigation. Another case had one lesion in each lobe of the liver, a hypodense mass in the left lobe and a cyst-like lesion in the right. Among the remaining 47 cases, on plain CT scanning, MFH appeared as hypodense masses with necrotic areas of differing degrees in 40 cases, cyst-like masses in 4 cases, mixed masses in 3 cases. 45 cases provided details on the enhancement scanning. The solid components or the cystic walls of 41 cases were introduced to be variably enhanced, from slightly to markedly, while the masses of the remaining 4 cases showed no enhancement. Among the 16 cases with MRI examinations, 2 cases provided no information of T1weighted MR images. The T1-weighted MR images of the remaining 14 cases all showed low signal-intensity masses. T2-weighted MR images of all the 16 cases showed high signal-intensity solid masses. 11 cases provided details on contrast-enhanced dynamic MR images. A gradual enhancement of internal components was present in 10 cases, and no obvious enhancement was showed in only 1 case.

For laboratory examinations, 5 cases provided no details. It showed that 77.8 percent $(35 / 45)$ of liver function tests and 60.8 percent $(31 / 51)$ of hepatitis investigations were normal in the patients. About the tumor marker, only a few of patients have slightly elevated tumor marker levels, such as serum alpha-fetoprotein (AFP, 7/68), carcinoembryonic antigen (CEA, 1/41), carbohydrate antigen 19-9 (CA19-9, 3/34). 5 cases have the 


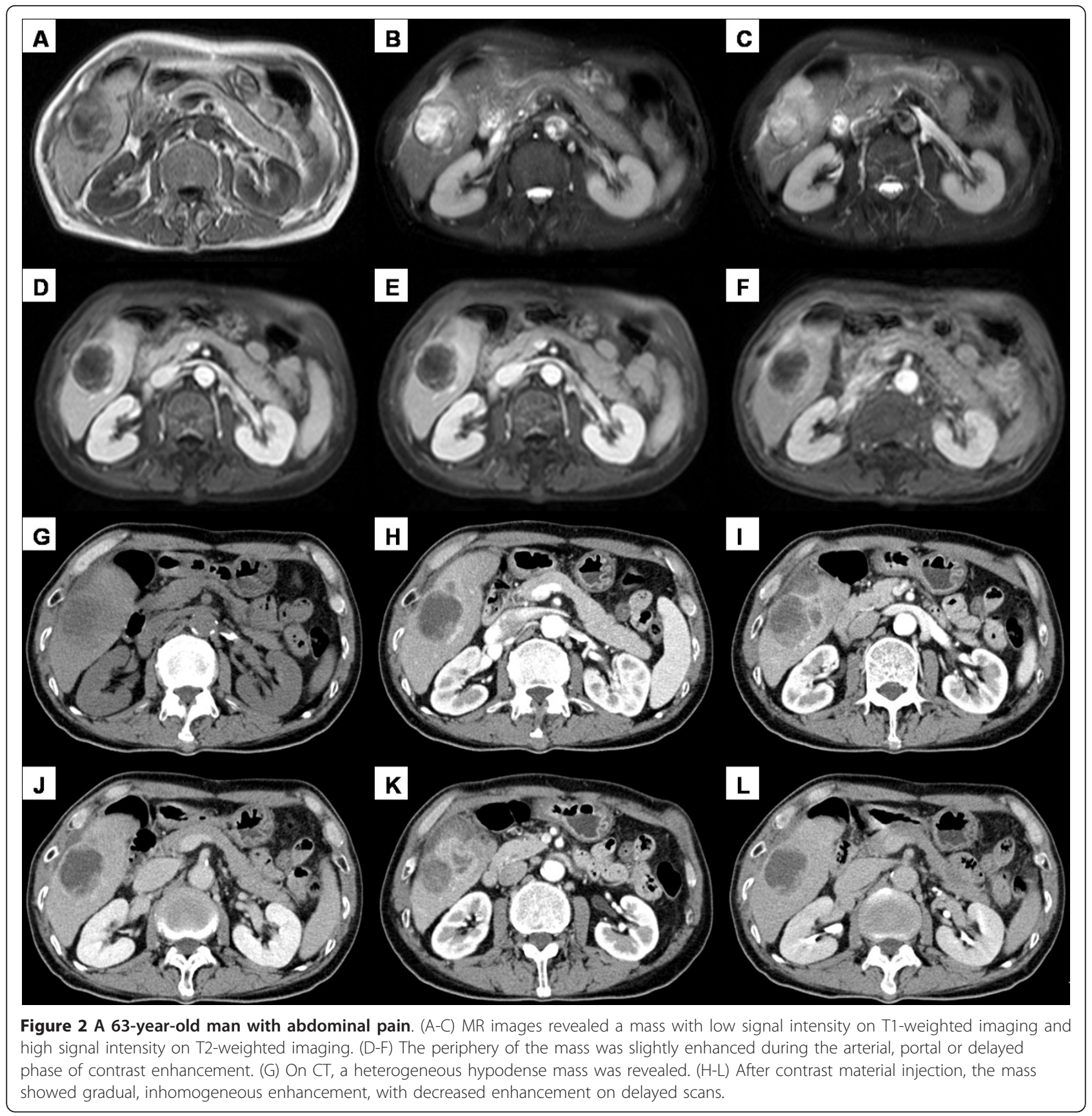

description of carbohydrate antigen 125 (CA125) examinations and only 1 patient has an elevated level.

Despite the technological advances, pre-operative diagnosis of hepatic MFH is still difficult, and the rate of misdiagnosis is extremely high. We had information about preoperative diagnosis for 67 patients, none of which, including one case with puncture biopsy before operation in our series, got the exact diagnosis. 48 cases were diagnosed as hepatic neoplasms, 8 cases were only diagnosed as masses of liver. In addition, 10 cases (14.9\%) were even misdiagnosed as benign lesions of the liver, including hemangioma in 3 cases, hepatophyma in 5 cases, hepatic hydatid cyst in 1 case and hepatic cyst in 1 case. The remaining 1 case was only diagnosed as calculi of intrahepatic duct, and the hepatic mass was not discovered until surgery.

Surgical procedure was the main treatment for hepatic MFH (Table 3). Among the 68 patients whose treatments were available, 49 cases $(72.1 \%)$ had integrated resection, 4 cases $(5.9 \%)$ had palliative operation (local resection), 7 cases had (10.3\%) puncture biopsy, and the other 8 cases $(11.8 \%)$ were found unresectable at 
Table 2 Clinicopathological characteristics of primary hepatic malignant fibrous histiocytoma

\begin{tabular}{|c|c|c|}
\hline & Number of patients & Percentage (\%) \\
\hline Sex & 76 & \\
\hline Male & 50 & 65.8 \\
\hline Female & 26 & 34.2 \\
\hline Age (years) & 59 & \\
\hline Older than 40 years & 52 & 88.1 \\
\hline Yonger than 40 years & 7 & 11.9 \\
\hline Clinical presentation & 74 & \\
\hline Abdominal pain or discomfort of differing degrees & 58 & 78.4 \\
\hline Asymptomatic & 11 & 14.9 \\
\hline Obstructive jaundice & 3 & 4.1 \\
\hline Fever & 17 & 22.8 \\
\hline Loss of body weight & 13 & 17.6 \\
\hline Nausea and anorexia & 8 & 10.8 \\
\hline Location & 66 & \\
\hline Left lobe & 24 & 36.4 \\
\hline Right lobe & 36 & 54.5 \\
\hline Right and left lobe & 6 & 9.1 \\
\hline Diameter $(\mathrm{cm})$ & 76 & \\
\hline Larger than $5 \mathrm{~cm}$ & 66 & 86.8 \\
\hline Smaller than $5 \mathrm{~cm}$ & 10 & 13.2 \\
\hline
\end{tabular}

laparotomy and underwent biopsy. In one case with integrated resection, a lesion in the lung was also detected synchronously with the one in the liver, and left pneumonectomy was performed 50 days after operation. The lesion of the lung was demonstrated as metastatic MFH and no adjunctive therapy was performed afterward. Among the remaining 48 vases with integrated resection, 3 cases received chemotherapy, 2 cases received radiation therapy, 1 case received hepatic artery and portal vein subcutaneous embedding alternate infusion chemotherapy after operation, 1 case received hepatic arterial infusion chemotherapy twice because of tumor recurrence 2 months after operation, and 1 case received lymphadenectomy and 125 I radiation therapy because of lymph nodes metastasis 3 months after operation. Among the 4 cases with palliative operation, 1 case received intrahepatic dehydrated alcohol injection and hepatic arterial chemoembolization six times and regular antituberculosis treatment because misdiagnosised as intrahepatic nonspecific inflammatory granuloma, HCC or tuberculosis respectively before operation, and after operation superselective arterial chemoembolization and hepaticarteriography chemoembolization were also performed, another case received drainage fenestrated with laparoscope because misdiagnosised great cyst in the left lobe of liver before laparotomy, and received palliative operation because of intraperitoneal plant. Among the 7 cases with puncture biopsy, 1 case received percutaneous cryoablation combined with transarterial chemoembolization. Among the 8 cases with biopsy after laparotomy, 2 cases received chemotherapy.

Most cases of primary hepatic MFH were the type of pleomorphic storiform MFH. One case in the Chinese literature was the type of inflammatory $\mathrm{MFH}$, which has not been reported in the English literature. In the English literature, the only case that was diagnosed as giant cell MFH was also from China. For immunohistochemical investigations, only 28 cases provided details. Immunohistochemically, the tumor cells showed typically positive for Vimentin(27/27), CD68(13/13), and

Table 3 Treatment and prognosis of primary hepatic malignant fibrous histiocytoma

\begin{tabular}{ll}
\hline & Number of patients \\
\hline Treatment & 68 \\
Integrated resection & 49 \\
Palliative operation (local resection) & 4 \\
Puncture biopsy & 7 \\
Biopsy after laparotomy & 8 \\
Follow-up & $42^{\dagger}$ \\
Recurrence or metastasis within a year & 10 \\
Recurrence or metastasis over a year & 2 \\
No recurrence or metastasis within a year & 5 \\
No recurrence or metastasis over a year & 2 \\
Died & $16^{\ddagger}$ \\
Alive & 6 \\
\hline
\end{tabular}

${ }^{\dagger}$ including one case that was lost after finding the lesion was increasing 4 month after operation. ₹ including 15 cases that died within a year and one case that died without the surviving time provided. 
MAC387(2/2), and AAT(13/14), Lysozyme(11/12), ACT (10/12) showed positive in most cases. AFP(5/5), FVIII (2/2), CEA(4/4), EMA(9/9), CK8/18(7/7), Hep parl(4/4), CD10(3/3), HMB-45(7/7), Actin(5/5), Desmin(13/13) showed all negative, and CK(1/12), CD34(1/5), S-100(1/ $10)$, SMA(1/5) were expressed only in a few tumors.

To our knowledge, follow-up periods ranging from one month to 10 years were mentioned for 42 patients. The 8 cases with no treatment introduction have no follow-up either. Among the 49 cases with integrated resection, a postoperative follow-up was conducted in 33 patients. 10 cases of these 33 patients had recurrence or metastasis within a year, 2 cases had recurrence or metastasis over a year, 5 cases had no recurrence or metastasis within a year, 2 cases had no recurrence or metastasis over a year, 8 cases died within a year, and the remaining 6 cases were still alive with no detail information provided (the follow-up periods of these 6 cases was 1 month, 3 months, 23 months, 26 months, 3 years and 10 years respectively). Among the 4 cases with palliative operation, 2 cases were followed-up. 1 case died of multiple organ failure 2 months after operation, and the other was lost after finding the lesion was increasing 4 month after operation. Among the 7 cases with puncture biopsy, 2 cases were followed-up, and died 1 month and half of 1 month respectively after discharge from hospital. Among the 8 cases with biopsy by operation, 5 cases were followed-up. 4 cases died 1 month, 2 month, 3 month and half of 1 year respectively after discharge from hospital, and 1 case died without the surviving time provided.

\section{Discussion}

Malignant fibrous histiocytoma (MFH) was first reported in 1964 by O'Brien and Stout[1] and has been considered to be one of the most common soft tissue sarcomas of late adult life[2]. Based on its morphological pleomorphism, five histologic subtypes of MFH were described by Enzinger and Weiss: pleomorphic storiform, myxoid, giant cell, inflammatory, and angiomatoid [2]. Now, according to the current WHO classification, myxoid MFH and angiomatoid MFH are no longer the subtypes of MFH, and the terms myxofibrosarcoma and angiomatoid fibrous histiocytoma are used for them. Myxofibrosarcoma has been reallocated from the fibrohistiocytic category to the myofibroblastic list and angiomatoid MFH is now classified under the category of tumors of uncertain differentiation [32].

MFH primarily occurs in the extremities and less commonly involves the retroperitoneal spaces, abdominal cavity, or other sites [3]. Primary hepatic MFH is exceedingly rare, especially in comparison with MFH of other sites, or with the more common primary malignancies of the liver $[2,33]$. Since its original description in 1985[5], to date, only 45 cases have been described in the English literature, including recent reports by Li et al. [27], Sugitani M et al. [28], Kim HS et al. [29], Caldeira A et al. [30] and Cong Z et al. [31]. Among the 45 cases, 8 cases were from China [24-26,31]. In the English literature, $\mathrm{Li}$ et al presented a series of 7 cases of primary hepatic MFH (including one case that was classified as myxoid type), which is the largest series to date. In our study, we review all well-documented reported cases of hepatic MFH in China before June 2011, and the largest series in the Chinese literature include 11 cases, among which one case was also classified as myxoid type. The cases of primary hepatic MFH were mostly the type of pleomorphic storiform. One case in the Chinese literature was the type of inflammatory MFH, which has not been reported in the English literature. In addition, in the English literature, the only case that was diagnosed as giant cell-type MFH was also from China.

For epidemiological characteristics of hepatic MFH, our study confirms previous reports on this neoplasm as a malignant entity, often with a large mass and predominantly affecting adult patients. However, there are also some differences in our study with previous ones. In the previous study in the English literature, patients were all older than 34, whereas in our study it is found that there are also 4 patients younger than 15 years old, including 1 boy and 3 girls, suggesting that the primary hepatic MFH could also occur among young persons. In addition, in a recent study of 34 cases, $\mathrm{Li}$ and colleagues showed that there was no sex predilection in the hepatic $\mathrm{MFH}$ [27], while in our study, 50 of 76 patients in China were men, with a male to female ratio of 1.9:1, suggesting that there might be a slight male predominance for the incidence of this rare malignant tumor. Certainly, these results still waits further confirmed in the future study.

The clinical presentation of primary hepatic MFH is nonspecific, including abdominal pain or discomfort, systemic symptoms of low-grade fever, malaise, anorexia, jaundice and weight loss, and nearly 14.9 percent (11 cases) of the patients in our study were asymptomatic. Spiking fever might also be a clinical presentation, such as 2 cases in the study of $\mathrm{Li}$ and colleagues [27], and 2 cases in our study. Consistent with previous studies, our study also confirms that radiological investigations of primary hepatic MFH are various and nonspecific. The lesions could be homogeneous solid [21], heterogeneous dense with areas of necrosis or nearly complete cystic changes [29] in the ultrasonography (US), CT or MRI examinations. After contrast administration, the solid components or the cystic walls mostly demonstrate variable enhancement. Delay enhancement can be observed and the intensity depends on the 
amount of fibrosis [21]. It's worth noting that though the lesions were usually detected and located by radiological investigations, specially, 1 case that was diagnosed as inflammatory MFH by biopsy was misdiagnosed only as calculi of intrahepatic duct before surgery, and the multiple hepatic masses in the left lobe of liver were not discovered until surgery. Laboratory examination also lack available and helpful indexes for preoperative diagnosis. 77.8 percent $(35 / 45)$ of liver function tests and 60.8 percent $(31 / 51)$ of hepatitis investigations were normal and the negative percentage of serum alpha-fetoprotein(AFP), carcinoembryonic antigen (CEA), CA19-9 and CA125 were all rather high, suggesting these tumor markers were not suitable predictors for this malignant hepatic tumor either.

Duo to the lack of the specification for the clinical presentations, images or tumor markers, the pre-operative diagnosis of hepatic MFH was rather difficult and the rate of pre-operative misdiagnosis was extremely high. In our study, none of the patients got the exact diagnosis. In addition, 10 cases (14.9\%) were even misdiagnosed as benign lesions of the liver, including hemangioma, hepatophyma, hepatic hydatid cyst and hepatic cyst. The misdiagnosis may usually make the effective treatment delayed, or even lead to error treatments, especially for the hepatic MFH with cyst masses. 1 case in our study received drainage fenestrated with laparoscope because misdiagnosised as a great cyst in the left lobe of liver before laparotomy, and afterward the patient received only palliative operation because of intraperitoneal plant, which might be caused by the drainage.

Surgical resection with negative resection margins is the mainstay of treatment for primary MFH of the liver. Though the prognosis of hepatic MFH is poor, there are still some cases with good prognosis and one case in our study was even alive 10 years after resection of the lesion. In the study of $\mathrm{Li}$ et al, it was also showed that up to $33 \%$ of patients survived for more than 2 years [27]. So, early diagnosis and effective treatment might be an effective method. Furthermore, repeated surgery after recurrence might be also effective [15,28]. Besides, consistent with previous studies, our study also suggests that adjunctive therapies, such as chemotherapy chemoembolization or radiation therapy, are not effective treatment for this rare tumor. In addition, one thing to be noted is that the patients with incomplete surgery or biopsy seem to have a worse prognosis. In our study, among the cases with palliative operation or only a biopsy, 9 cases were followed-up and there were 7 cases that died within half a year after discharge from hospital, 1 case that died without the surviving time provided and 1 case that was lost after the lesion was found to increase 4 month after operation. Moreover, none of the
8 cases that survived more than 2 years in the English literature just received a biopsy $[7,9,12,14,15,27-29]$.

\section{Conclusions}

Although hepatic MFH is a rare malignant mesenchymal tumor, it should also be considered in the diagnosis of large liver lesions. The features of clinical presentations and images are variable and the pre-operative diagnosis is difficult. Surgical resection is the most effective means for treating this rare tumor. Though the prognosis is poor, complete surgery with negative resection margins might provide a few of cases a good opportunity for surviving. Surgery again may be also useful for a recurrent tumor.

\section{Consent}

Written informed consent was obtained from the patient for publication of this Case report and any accompanying images. A copy of the written consent is available for review by the Editor-in-Chief of this journal.

\section{Abbreviations}

MFH: Malignant fibrous histiocytoma.

\section{Authors' contributions}

Yao DB participated in the design of the study, searched, studied and analyzed the data, and drafted the manuscript. Dai $C L$ conceived of the study, participated in its design and helped to draft the manuscript. All authors read and approved the final manuscript.

\section{Competing interests}

The authors declare that they have no competing interests.

Received: 31 July 2011 Accepted: 5 January 2012

Published: 5 January 2012

\section{References}

1. O'Brien JE, Stout AP: Malignant fibrous xanthomas. Cancer 1964 17:1445-55.

2. Weiss SW, Enzinger FM: Malignant fibrous histiocytoma: an analysis of 200 cases. Cancer 1978, 41:2250-66.

3. Kransdorf MJ: Malignant soft-tissue tumors in a large referral population: distribution of diagnoses by age, sex, and location. AJR Am J Roentgenol 1995, 164:129-34.

4. Matushansky I, Charytonowicz E, Mills J, Siddiqi S, Hricik T, Cordon-Cardo C: MFH classification: differentiating undifferentiated pleomorphic sarcoma in the 21st Century. Expert Rev Anticancer Ther 2009, 9:1135-44.

5. Alberti-Flor JJ, O'Hara MF, Weaver F, Evans J, McClure R, Dunn GD: Malignant fibrous histiocytoma of the liver. Gastroenterology 1985, 89:890-3.

6. Conran RM, Stocker JT: Malignant fibrous histiocytoma of the liver-a case report. Am J Gastroenterol 1985, 80:813-5.

7. Fukayama M, Koike M: Malignant fibrous histiocytoma arising in the liver. Arch Pathol Lab Med 1986, 110:203-6.

8. Arends JW, Willebrand D, Blaauw AM, Bosman FT: Primary malignant fibrous histiocytoma of the liver-a case report with immunocytochemical observations. Histopathology 1987, 11:427-31.

9. Bruneton JN, Drouillard J, Rogopoulos A, Laurent F, Normand F, BaluMaestro C, Monticelli J: Extraretroperitoneal abdominal malignant fibrous histiocytoma. Gastrointest Radiol 1988, 13:299-305.

10. Honda H, Nakamura Y, Kajiwara T, Muranaka T, Yoshida K, Tomooka K, Oshiumi $Y$, Teshima K: Malignant fibrous histiocytoma of the liver. Comput Med Imaging Graph 1988, 12:131-4. 
11. Katsuda S, Kawahara E, Matsui Y, Ohyama S, Nakanishi I: Malignant fibrous histiocytoma of the liver: a case report and review of the literature. Am J Gastroenterol 1988, 83:1278-82.

12. Hamasaki K, Mimura H, Sato S, Sakai H, Miyashima T, Gochi A, Orita K: Malignant fibrous histiocytoma of the liver-a case report. Gastroenterol Jpn 1991, 26:666-73.

13. Akifuji Y, Honjo I, Katayama S, Ishitobi S, Ueki J, Kishi K, Kato K, Nakamoto S: Malignant fibrous histiocytoma of the liver: a case report and review of the literature. Intern Med 1992, 31:284-8.

14. Zornig C, Kremer B, Henne-Bruns D, Weh HJ, Schröder S, Brölsch CE: Primary sarcoma of the liver in the adult. Report of five surgically treated patients. Hepatogastroenterology 1992, 39:319-21.

15. McGrady BJ, Mirakhur MM: Recurrent malignant fibrous histiocytoma of the liver. Histopathology 1992, 21:290-2.

16. Reed JG, Goodman P, Soloway RD: Primary malignant fibrous histiocytoma of the liver MRI findings. Magn Reson Imaging 1993, 11:139-43

17. Pinson CW, Lopez RR, Ivancev K, Ireland K, Sawyers JL: Resection of primary hepatic malignant fibrous histiocytoma, fibrosarcoma, and leiomyosarcoma. South Med J 1994, 87:384-91.

18. Fujita S, Lauwers GY: Primary hepatic malignant fibrous histiocytoma: report of a case and review of the literature. Pathol Int 1998, 48:225-9.

19. Wunderbaldinger P, Schima W, Harisinghani M, Saini S: Primary malignant fibrous histiocytoma of the liver: CT and MR findings. AJR Am J Roentgenol 1998, 171:900-1.

20. Ferrozzi F, Bova D: Hepatic malignant fibrous histiocytoma: CT findings. Clin Radiol 1998, 53:699-701.

21. Yu JS, Kim KW, Kim CS, Yoon KH, Jeong HJ, Lee DG: Primary malignant fibrous histiocytoma of the liver: imaging features of five surgically confirmed cases. Abdom Imaging 1999, 24:386-91.

22. Maekawa T, Yabuki K, Sato K, Tamasaki Y, Maekawa H, Ogawa K, Hirano A, Eguchi M, Matsumoto M: A case of fibrous histiocytoma of the liver. Nihon Geka Hokan 1999, 68:14-23.

23. Anagnostopoulos G, Sakorafas GH, Grigoriadis K, Kostopoulos P: Malignant fibrous histiocytoma of the liver: a case report and review of the literature. Mt Sinai J Med 2005, 72:50-2.

24. Ding GH, Wu MC, Yang JH, Cheng SQ, Li N, Liu K, Dai BH, Cong WM: Primary hepatic malignant fibrous histiocytoma mimicking cystadenocarcinoma: a case report. Hepatobiliary Pancreat Dis Int 2006, 5:620-3.

25. Ye MF, Zheng S, Xu JH, Chen LR: Primary hepatic malignant fibrous histiocytoma: a case report and review of the literature. Histol Histopathol 2007, 22:1337-42.

26. Chen $\mathrm{HC}$, Chen CJ, Jeng CM, Yang CM: Malignant fibrous histiocytoma presenting as hemoperitoneum mimicking hepatocellular carcinoma rupture. World J Gastroenterol 2007, 13:6441-3.

27. Li YR, Akbari E, Tretiakova MS, Hart J, Akbari M, Urbanski SJ, Gao ZH: Primary hepatic malignant fibrous histiocytoma: clinicopathologic characteristics and prognostic value of ezrin expression. Am J Surg Pathol 2008, 32:1144-58.

28. Sugitani M, Aramaki O, Kikuchi K, Sheikh A, Oinuma T, Mamiya T, Takayama T, Nemoto N: Two cases of primary malignant fibrous histiocytoma of the liver: immunohistochemical expression of ezrin and its relationship with prognosis. Acta Histochem Cytochem 2009, 42:83-8.

29. Kim HS, Kim GY, Lim SJ, Lee SM, Kim YW: Undifferentiated pleomorphic sarcoma of the liver presenting as a unilocular cyst. Hepatobiliary Pancreat Dis Int 2009, 8:541-3.

30. Caldeira A, Martin-Carreras F, Pereira E, Sousa R, Gonçalves R, Tristan J, Banhudo A: Malignant fibrous histiocytoma-a rare hepatic tumor. Rev Esp Enferm Dig 2010, 102:146-7.

31. Cong Z, Gong J: Primary malignant fibrous histiocytoma of the liver: CT findings in five histopathological proven patients. Abdom Imaging 2011, 36:552-556.

32. Fletcher CD: The evolving classification of soft tissue tumours: an update based on the new WHO classification. Histopathology 2006, 48:3-12.

33. Ishak KG, Goodman ZD, Stocker JT: Malignant mesenchymal tumors. In Tumors of the Liver and Intrahepatic Bile Ducts. Fascicle 31, Atlas of Tumor Pathology, Third Series. Edited by: Rosai J, Sobin LH. Armed Forces Institute of Pathology, Washington DC; 2001:280-330. doi:10.1186/1477-7819-10-2

Cite this article as: Yao and Dai: Clinical characteristics of the primary hepatic malignant fibrous histiocytoma in China: case report and review of the literature. World Journal of Surgical Oncology 2012 10:2.

\section{Submit your next manuscript to BioMed Central and take full advantage of:}

- Convenient online submission

- Thorough peer review

- No space constraints or color figure charges

- Immediate publication on acceptance

- Inclusion in PubMed, CAS, Scopus and Google Scholar

- Research which is freely available for redistribution

Submit your manuscript at www.biomedcentral.com/submit
C Biomed Central 